\title{
Hydrogeochemical Characterization and Quality Assessment of Groundwater in a Long-Term Reclaimed Water Irrigation Area, North China Plain
}

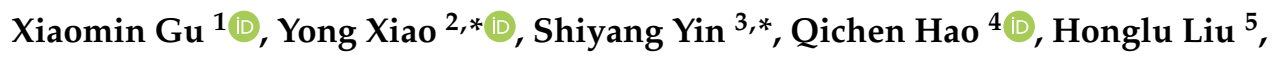 \\ Zhongyong Hao ${ }^{5}$, Geping Meng ${ }^{6}$, Qiuming Pei ${ }^{2}\left(\mathbb{D}\right.$ and Huijun Yan ${ }^{7}$ \\ 1 School of Geographic Science, Nantong University, Nantong 226000, China; ntugxm@ntu.edu.cn \\ 2 Faculty of Geosciences and Environmental Engineering, Southwest Jiaotong University, \\ Chengdu 611756, China; pqm@swjtu.edu.cn \\ 3 School of Renewable Energy, North China Electric Power University, Beijing 102206, China \\ 4 Institute of Hydrogeology and Environmental Geology, Chinese Academy of Geological Science, \\ Shijiazhuang 050061, China; haoqichen@mail.cgs.gov.cn \\ 5 Beijing Water Science and Technology Institute, Beijing 100044, China; liuhonglu@yeah.net (H.L.); \\ haozhongyong2002@163.com (Z.H.) \\ 6 Beijing Daxing Water Resources Bureau, Beijing 102600, China; mgpmbx@aliyun.com \\ 7 Geological Environmental Monitoring Central Station of Qinghai Province, Xining 810008, China; \\ yanhj1214@aliyun.com \\ * Correspondence: xiaoyong@swjtu.edu.cn (Y.X.); yinshiyang1984@163.com (S.Y.); \\ Tel.: +86-180-1000-8002 (Y.X.); +86-010-5150-3095 (S.Y.)
}

Received: 29 July 2018; Accepted: 5 September 2018; Published: 7 September 2018

\begin{abstract}
Water scarcity has led to wide use of reclaimed water for irrigation worldwide, which may threaten groundwater quality. To understand the status of groundwater in the reclaimed water irrigation area in Beijing, 87 samples from both shallow and deep aquifers were collected to determine the factors affecting groundwater chemistry and to assess groundwater quality for drinking and irrigation purposes. The results show that groundwater in both shallow and deep aquifers in the study area is weakly alkaline freshwater with hydrogeochemical faces dominated by $\mathrm{HCO}_{3}-\mathrm{Na} \cdot \mathrm{Mg} \cdot \mathrm{Ca}$, $\mathrm{HCO}_{3}-\mathrm{Mg} \cdot \mathrm{Ca} \cdot \mathrm{Na}, \mathrm{HCO}_{3}-\mathrm{Ca} \cdot \mathrm{Na}$, and $\mathrm{HCO}_{3}-\mathrm{Na}$. The chemical composition of groundwater in both shallow and deep aquifers is dominantly controlled by the dissolution of halite, gypsum, anhydrite, and silicates weathering, as well as ion exchange. Geogenic processes (rock weathering and ion exchange) are the only mechanisms controlling groundwater chemistry in deep aquifers. Besides geogenic processes, evaporation and anthropogenic activities also affect the chemistry of shallow groundwater. Quality assessment reveals that both shallow and deep groundwater are generally suitable for drinking and irrigation purposes. The quality of deep groundwater is more excellent for drinking than shallow groundwater. However, long-term use of deep groundwater for irrigation exhibits higher potential risks to deteriorate soil property due to the relative higher permeability indexes (PI). Therefore, it is recommended that deep groundwater is preferentially used for drinking and domestic purpose, and shallow groundwater for agricultural irrigation.
\end{abstract}

Keywords: hydrochemistry; influencing factors; groundwater quality assessment; EWQI; Beijing

\section{Introduction}

Water scarcity has been one of the most serious problems that restrict economic development in many regions around the world, especially in arid and semiarid regions [1,2]. Due to the spatio-temporal availability and easy accessibility, groundwater becomes the major source of freshwater 
for agricultural, domestic, and industrial purposes [3,4]. These purposes are dominantly controlled by groundwater chemistry [5]. Therefore, comprehending the characterization of groundwater chemistry and its controlling factors is vital for preservation and proper management of these precious resources, as well as realizing sustainable use of groundwater [6,7].

As one of the water shortage megacities in the world, Beijing relies heavily upon groundwater resources for its various usages, over $60 \%$ of annual total water supply quantity is groundwater [3]. Due to long-term overexploitation, groundwater level has declined sharply during the past decades [8]. In order to alleviate the water shortage, wastewater and reclaimed water have been utilized for agricultural irrigation in Beijing Plain since the 1950s [9]. Water reuse for irrigation may lead to some negative environmental consequences, such as soil structure deterioration, enrichment of heavy metals and other pollutants in soils and agricultural corps, groundwater pollution as well $[9,10]$. Numerous researches have been conducted to get insight into these consequences, but most of them concentrated on the effects on soil and plant [11-15]. Only a few researches were concerned on the influences of this reuse on groundwater [9,16-18]. For example, Bao et al. found that long-term wastewater irrigation had resulted in nutrient elements and heavy metals accumulation in soil at some extent, but it did not constitute pollution in shallow groundwater [16,19]. Wang et al. reported that nonylphenol, a kind of organic pollutant from wastewater, had been found existing in groundwater, and its distribution and concentration in groundwater were related to the measure of wastewater irrigation and groundwater depth [18]. Niu et al. applied geostatistics to determine the spatial variation of groundwater quality in a reclaimed water irrigation area in Beijing, and found that reclaimed water irrigation was not the major factor influencing groundwater quality [17]. However, the hydrogeochemical characterization and quality of groundwater in wastewater and reclaimed water irrigation areas are still not well known. This may limit the protection and proper utilization of groundwater resources in Beijing, especially in reclaimed water irrigation areas.

The aims of this study are (1) to address the hydrochemical characterization of groundwater in Beijing's reclaimed water irrigation area, (2) to identify the factors influencing the chemical composition of groundwater, and (3) to assess the suitability of groundwater quality for drinking and agricultural irrigation purposes. This work will be helpful in the protection and management of groundwater in Beijing, and be useful for groundwater resources management in another part of the world facing the similar situation.

\section{Materials and Methods}

\subsection{Study Area}

The study area is located in the southeastern part of the Beijing plain with longitudes of $116^{\circ} 32^{\prime}-116^{\circ} 43^{\prime} \mathrm{E}$ and latitudes of $39^{\circ} 26^{\prime}-40^{\circ} 02^{\prime} \mathrm{N}$. It covers an area of about $373 \mathrm{~km}^{2}$ (Figure 1). It is characterized by a temperate continental monsoon climate. The average annual rainfall in the study area is $554.5 \mathrm{~mm}$, with approximate $70 \%$ occurred from June to September. While the annual potential evaporation rate is $1800 \mathrm{~mm}$, which is about three times of the annul precipitation.

As shown in the Figure 2, the terrain of this area is flat, with a slight gradual slop from northwest to southeast. The study area is located in the downstream area of Yongding River and Chaobai River watershed and formed by their alluvial sediments. The Quaternary deposits distribute widely and the thickness gradually increases from northwest to southeast with a maximum thickness of $300 \mathrm{~m}$. The strata present an alternating lithologic structure of middle-fine sand and clay. A continuous clay layer is found at a depth of $80 \mathrm{~m}$, above and below which are defined as the shallow aquifer and deep aquifer, respectively [16]. Groundwater is loose-rock pore water occurring in the Quaternary aquifers and flows from northwest to southeast regionally. The water level depth of shallow aquifer ranges from 4 to $9 \mathrm{~m}$, and that of deep aquifer varies from 17 to $21 \mathrm{~m}$ (Figure 2). The main components of groundwater recharge include lateral inflow, precipitation infiltration, river and canal leakage, and irrigation infiltration, while the major discharge patterns are artificial abstraction, evaporation, and lateral outflow. 
Located in the southeast suburb of Beijing, a large area of farmland was distributed in the study area. Due to lack of water resource, urban sewage was used for agricultural irrigation in the study area since 1969, leading to a sewage irrigation history of over 30 years [9]. Since 2003, reclaimed water from Gaobeidian, Xiaohongmen, and Huangcun wastewater treatment plants (Figure 1) has gradually replaced wastewater and became the major water resource for irrigation in the study area [14,18].

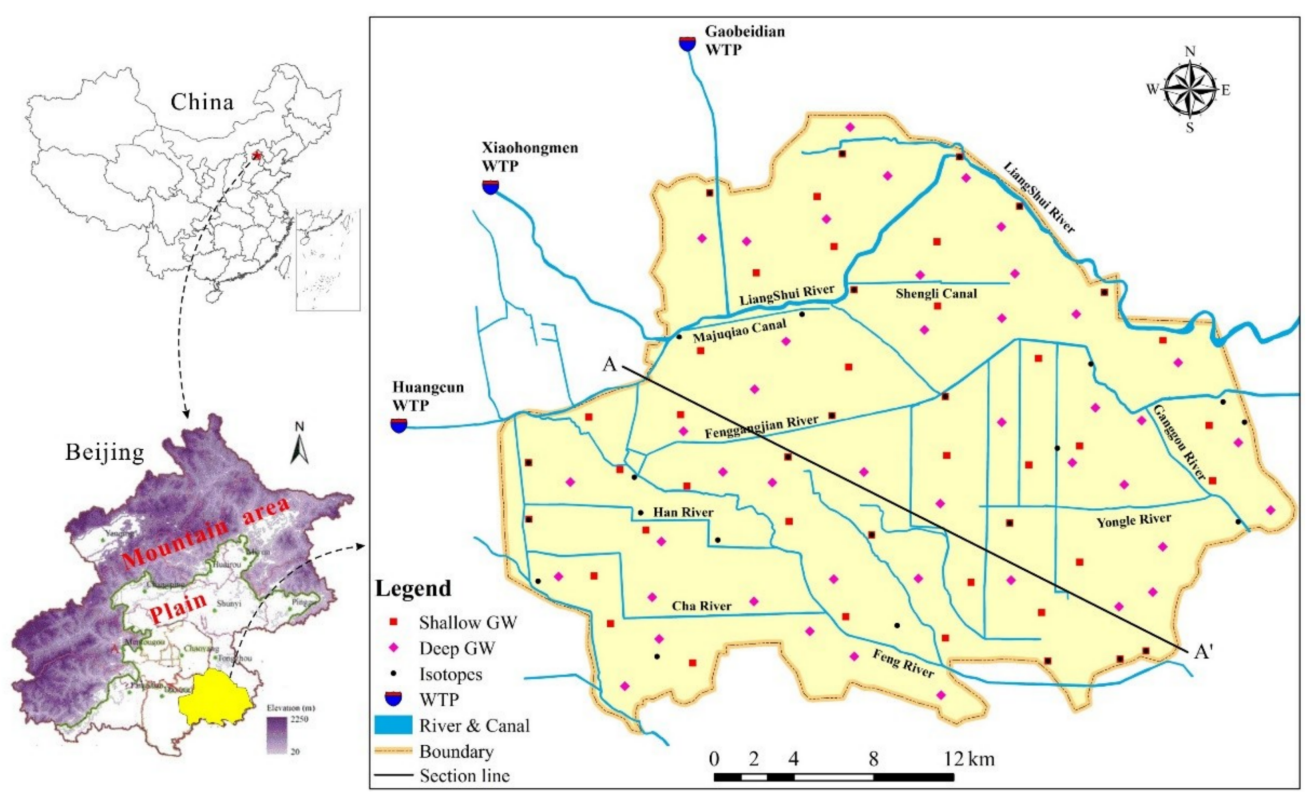

Figure 1. Location of the study area and sampling sites.

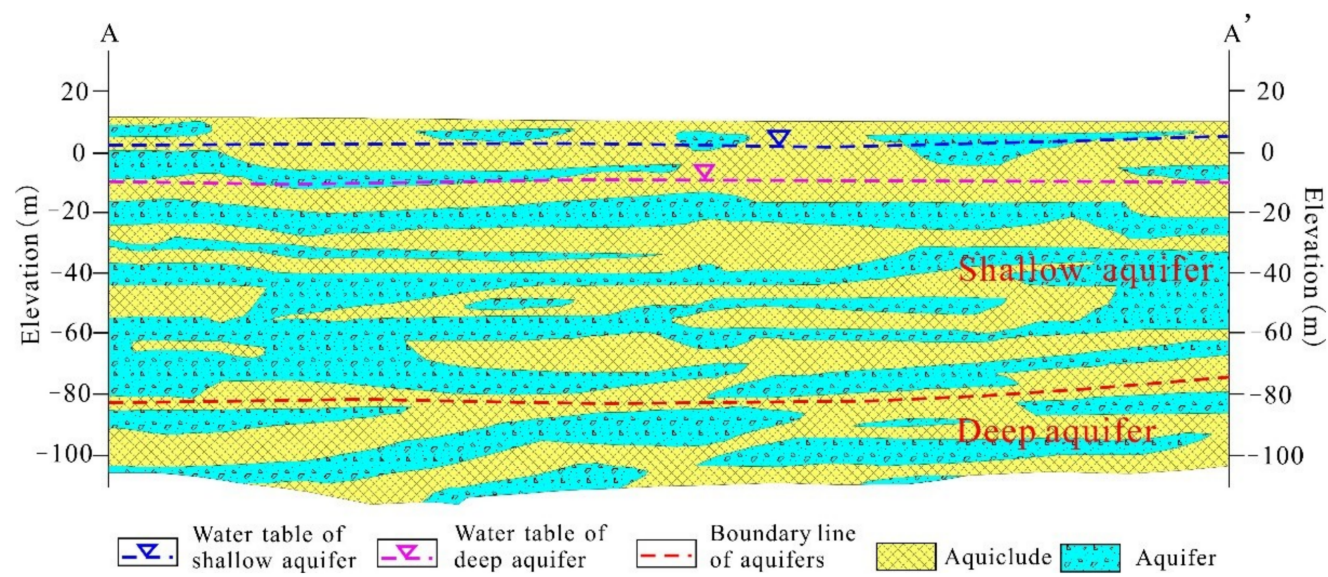

Figure 2. Hydrogeological cross section of the study area.

\subsection{Sample Collection and Analysis}

For this study, 87 groundwater samples, including 44 samples from shallow aquifer and 43 samples from deep aquifer (Figure 1), were collected from boreholes in October 2016 for physiochemical analysis. Prior to sampling, all of the boreholes were pumped for fifteen minutes to remove the stagnant water. Samples were collected in $2.5 \mathrm{~L}$ plastic bottles that had been thoroughly pre-cleaned while using the water to be sampled. Temperature $(\mathrm{T})$, hydrogen ion activity $(\mathrm{pH})$, electrical conductance (EC), and total dissolved solids (TDS) were measured in the field while using a multi-parameter device (Multi 350i/SET). The other analyzed indices including major ions $\left(\mathrm{Na}^{+}, \mathrm{K}^{+}, \mathrm{Ca}^{+}, \mathrm{Mg}^{+}, \mathrm{Cl}^{-}, \mathrm{SO}_{4}{ }^{2-}\right.$, $\left.\mathrm{HCO}_{3}{ }^{-}\right)$, nitrate $\left(\mathrm{NO}_{3}{ }^{-}\right)$, nitrite $\left(\mathrm{NO}_{2}{ }^{-}\right)$, and ammonia $\left(\mathrm{NH}_{4}{ }^{+}\right)$were measured at the Laboratory of Groundwater Sciences and Engineering of the Institute of Hydrogeology and Environmental Geology, Chinese Academy of Geological Sciences (LGSE-IHEG-CAGS). The laboratory analysis were carried out 
following the analytical methods that were described by Huang et al. [20]. Major cations, including $\mathrm{Na}^{+}$, $\mathrm{K}^{+}, \mathrm{Ca}^{+}, \mathrm{Mg}^{+}$were analyzed while using inductively coupled plasma-mass spectrometry (Agilent $7500 \mathrm{ce}$ ICP-MS, Tokyo, Japan). $\mathrm{Cl}^{-}$and $\mathrm{SO}_{4}{ }^{2-}$ were measured by spectrophotometry (PerkinElmer Lambda 35, Waltham, MA, USA). $\mathrm{HCO}_{3}{ }^{-}$and TDS were determined by acid-base titration and gravimetric analysis, respectively. The percent charge balance errors of all samples were within $\pm 5 \%$.

In order to get insight into the effects of evaporation on groundwater chemical composition, 29 groundwater samples were collected from shallow aquifer for analysis of deuterium and oxygen-18. Isotopic analysis of ${ }^{2} \mathrm{H}$ and ${ }^{18} \mathrm{O}$ were also performed at LGSE-IHEG-CAGS, following the methods described by Liu et al. [21]. The results were reported in $\delta$ notation relative to the V-SMOW standard (Vienna Standard Mean Ocean Water) for oxygen and hydrogen, and the precision is within $\pm 0.05 \%$ and $\pm 0.1 \%$, respectively.

\section{Results and Discussion}

\subsection{General Hydrochemical Characteristics}

Table 1 lists the statistical analysis results of the physio-chemical indices of all samples. Groundwater $\mathrm{pH}$ is observed in the range of 7.20-8.40 in the shallow aquifer and ranges from 7.40 to 8.40 in the deep aquifer, suggesting that both shallow and deep groundwater in the study area is weakly alkaline water. TDS and EC of groundwater in the shallow aquifer are observed in the ranges of $266-1230 \mathrm{mg} / \mathrm{L}$ and $408-1869 \mu \mathrm{S} / \mathrm{cm}$, respectively, and those in the deep aquifer are $312-647 \mathrm{mg} / \mathrm{L}$ and $456-945 \mu \mathrm{S} / \mathrm{cm}$, respectively. The salinity of shallow groundwater is higher than that of deep groundwater.

Cations and anions show significant difference in shallow and deep groundwater. As shown in Table 1, the concentrations of $\mathrm{Na}^{+}, \mathrm{K}^{+}, \mathrm{Ca}^{2+}$ and $\mathrm{Mg}^{2+}$ in shallow groundwater are observed in the ranges of $9.30-257 \mathrm{mg} / \mathrm{L}, 0.270-9.93 \mathrm{mg} / \mathrm{L}, 20.2-161 \mathrm{mg} / \mathrm{L}, 0.960-97.1 \mathrm{mg} / \mathrm{L}$, respectively, and those in deep groundwater range within $6.40-139 \mathrm{mg} / \mathrm{L}, 0.240-5.14 \mathrm{mg} / \mathrm{L}, 22.2-82.6 \mathrm{mg} / \mathrm{L}$, and $0.580-93.0 \mathrm{mg} / \mathrm{L}$, respectively. For both shallow and deep groundwater, $\mathrm{Na}^{+}$has the highest concentration value, followed by $\mathrm{Ca}^{2+}$ and $\mathrm{Mg}^{2+}$, and $\mathrm{K}^{+}$has the lowest abundance. While the concentrations of $\mathrm{Na}^{+}, \mathrm{Ca}^{2+}$, and $\mathrm{Mg}^{2+}$ in shallow groundwater are much higher than that in deep groundwater. Due to the high abundance of those cations in wastewater and reclaimed water [22], their use for irrigation results in elevation of the concentrations of $\mathrm{Na}^{+}, \mathrm{Ca}^{2+}, \mathrm{Mg}^{2+}$ in shallow groundwater [23]. The concentrations of $\mathrm{HCO}_{3}{ }^{-}$, $\mathrm{SO}_{4}{ }^{2-}$, and $\mathrm{Cl}^{-}$in shallow groundwater range within $155-694 \mathrm{mg} / \mathrm{L}, 9.0-197 \mathrm{mg} / \mathrm{L}$, and $12.3-167 \mathrm{mg} / \mathrm{L}$, respectively. Those in deep groundwater are found in the range of $164-436 \mathrm{mg} / \mathrm{L}, 5.0-91.0 \mathrm{mg} / \mathrm{L}$, and $8.80-86.2 \mathrm{mg} / \mathrm{L}$, respectively. For both shallow and deep groundwater, the abundance of anions is in the following order: $\mathrm{HCO}_{3}{ }^{-}>\mathrm{SO}_{4}{ }^{2-}>\mathrm{Cl}^{-}$. Also, a higher abundance of anions is observed in shallow groundwater.

Nitrate is a very common groundwater pollutant in many regions in the world [24], and most of this contamination are from agriculture and sewage effluent containing high nitrate concentration $[25,26]$. In this study, the concentration of $\mathrm{NO}_{3}{ }^{-}$in shallow groundwater ranges from $0.15 \mathrm{mg} / \mathrm{L}$ to $19.3 \mathrm{mg} / \mathrm{L}$ with the mean value of $3.84 \mathrm{mg} / \mathrm{L}$, and that in deep groundwater ranges within $0.20-3.83 \mathrm{mg} / \mathrm{L}$ with the average value of $0.91 \mathrm{mg} / \mathrm{L}$. The upper geochemical limit for nitrate is $10 \mathrm{mg} / \mathrm{L}$, any value exceeding the value is considered as pollution due to external factors [27]. Therefore, nitrate pollution was existed in the shallow aquifer, while no nitrate pollution has been found in the deep aquifer. While considering the maximum and mean value of nitrate in shallow groundwater, the nitrate pollution is not serous in the study area. Nitrite and ammonium can also indicate the groundwater pollution. The abundance of these two constituents in shallow groundwater is in the range of $0.00-1.21 \mathrm{mg} / \mathrm{L}$ and $0.02-4.11 \mathrm{mg} / \mathrm{L}$, with the average value of $0.03 \mathrm{mg} / \mathrm{L}$ and $0.25 \mathrm{mg} / \mathrm{L}$, respectively. While that in deep aquifer ranges within $0.00-0.09 \mathrm{mg} / \mathrm{L}$ and $0.02-0.50 \mathrm{mg} / \mathrm{L}$ with the mean value of $0.01 \mathrm{mg} / \mathrm{L}$ and $0.07 \mathrm{mg} / \mathrm{L}$, respectively (Table 1). All above indicate that shallow groundwater has been polluted by nitrogen from agriculture and sewage effluent. 
A Durov diagram (Durov 1948) was generated to examine the hydrochemical characteristics of groundwater in the study area (Figure 3). As shown in Figure 3, the majority of the deep groundwater samples have TDS less than $500 \mathrm{mg} / \mathrm{L}$ and $\mathrm{HCO}_{3}^{-}$is the dominant anion. While the shallow groundwater samples had a larger variated range of TDS content varying from $300 \mathrm{mg} / \mathrm{L}$ to $1300 \mathrm{mg} / \mathrm{L}$, also dominated by $\mathrm{HCO}_{3}{ }^{-}$. All the samples from both shallow and deep aquifers have similar concentration of cations. The larger variated range of TDS in shallow groundwater indicates that the quality of shallow groundwater is effected by evaporation and irrigated water infiltration. According to the Durov diagram, groundwater type in both shallow and deep aquifers in the area are mainly $\mathrm{HCO}_{3}-\mathrm{Na} \cdot \mathrm{Mg} \cdot \mathrm{Ca}, \mathrm{HCO}_{3}-\mathrm{Mg} \cdot \mathrm{Ca} \cdot \mathrm{Na}, \mathrm{HCO}_{3}-\mathrm{Ca} \cdot \mathrm{Na}$, and $\mathrm{HCO}_{3}-\mathrm{Na}$.

Table 1. Statistical analysis of groundwater samples.

\begin{tabular}{|c|c|c|c|c|c|c|c|c|}
\hline & Index & Unit & Sample No. & Min & Max & Mean & SD & $\begin{array}{l}\text { WHO Guideline } \\
\text { (2011) [28] }\end{array}$ \\
\hline \multirow{13}{*}{ Shallow GW } & $\mathrm{Ca}$ & $\mathrm{mg} / \mathrm{L}$ & 44 & 20.20 & 161.00 & 85.19 & 35.28 & 75 \\
\hline & $\mathrm{Mg}$ & $\mathrm{mg} / \mathrm{L}$ & 44 & 0.96 & 97.10 & 48.88 & 23.42 & 50 \\
\hline & $\mathrm{Na}$ & $\mathrm{mg} / \mathrm{L}$ & 44 & 9.30 & 257.00 & 104.67 & 43.07 & 50 \\
\hline & K & $\mathrm{mg} / \mathrm{L}$ & 44 & 0.27 & 9.93 & 1.94 & 1.82 & - \\
\hline & $\mathrm{HCO}_{3}$ & $\mathrm{mg} / \mathrm{L}$ & 44 & 155.00 & 694.00 & 470.34 & 131.39 & 500 \\
\hline & $\mathrm{SO}_{4}$ & $\mathrm{mg} / \mathrm{L}$ & 44 & 9.00 & 197.00 & 80.91 & 47.65 & 250 \\
\hline & $\mathrm{Cl}$ & $\mathrm{mg} / \mathrm{L}$ & 44 & 12.30 & 167.00 & 65.08 & 41.73 & 250 \\
\hline & TDS & $\mathrm{mg} / \mathrm{L}$ & 44 & 266.00 & 1230.00 & 698.23 & 228.46 & 500 \\
\hline & $\mathrm{EC}$ & $\mu \mathrm{S} / \mathrm{cm}$ & 44 & 408.00 & 1869.00 & 1034.16 & 326.74 & 500 \\
\hline & $\mathrm{pH}$ & - & 44 & 7.20 & 8.40 & 7.77 & 0.33 & $6.5-8.5$ \\
\hline & $\mathrm{NH}_{4}-\mathrm{N}$ & $\mathrm{mg} / \mathrm{L}$ & 44 & 0.02 & 4.11 & 0.25 & 0.71 & - \\
\hline & $\mathrm{NO}_{2}-\mathrm{N}$ & $\mathrm{mg} / \mathrm{L}$ & 44 & 0.00 & 1.21 & 0.03 & 0.18 & 3 \\
\hline & $\mathrm{NO}_{3}-\mathrm{N}$ & $\mathrm{mg} / \mathrm{L}$ & 44 & 0.15 & 19.30 & 3.84 & 4.90 & 45 \\
\hline \multirow{13}{*}{ Deep GW } & $\mathrm{Ca}$ & $\mathrm{mg} / \mathrm{L}$ & 43 & 22.20 & 82.60 & 42.08 & 11.99 & 75 \\
\hline & $\mathrm{Mg}$ & $\mathrm{mg} / \mathrm{L}$ & 43 & 0.58 & 93.00 & 20.73 & 14.05 & 50 \\
\hline & $\mathrm{Na}$ & $\mathrm{mg} / \mathrm{L}$ & 43 & 6.40 & 139.00 & 72.93 & 35.12 & 50 \\
\hline & K & $\mathrm{mg} / \mathrm{L}$ & 43 & 0.24 & 5.14 & 1.37 & 0.84 & - \\
\hline & $\mathrm{HCO}_{3}$ & $\mathrm{mg} / \mathrm{L}$ & 43 & 164.00 & 436.00 & 283.19 & 67.60 & 500 \\
\hline & $\mathrm{SO}_{4}$ & $\mathrm{mg} / \mathrm{L}$ & 43 & 5.00 & 91.00 & 45.59 & 19.17 & 250 \\
\hline & $\mathrm{Cl}$ & $\mathrm{mg} / \mathrm{L}$ & 43 & 8.80 & 86.20 & 24.27 & 14.41 & 250 \\
\hline & TDS & $\mathrm{mg} / \mathrm{L}$ & 43 & 312.00 & 647.00 & 383.88 & 67.12 & 500 \\
\hline & $\mathrm{EC}$ & $\mu \mathrm{S} / \mathrm{cm}$ & 43 & 456.00 & 945.00 & 622.37 & 97.10 & 500 \\
\hline & $\mathrm{pH}$ & - & 43 & 7.40 & 8.40 & 8.07 & 0.30 & $6.5-8.5$ \\
\hline & $\mathrm{NH}_{4}-\mathrm{N}$ & $\mathrm{mg} / \mathrm{L}$ & 43 & 0.02 & 0.50 & 0.07 & 0.12 & - \\
\hline & $\mathrm{NO}_{2}-\mathrm{N}$ & $\mathrm{mg} / \mathrm{L}$ & 43 & 0.00 & 0.09 & 0.01 & 0.01 & 3 \\
\hline & $\mathrm{NO}_{3}-\mathrm{N}$ & $\mathrm{mg} / \mathrm{L}$ & 43 & 0.20 & 3.83 & 0.91 & 0.88 & 45 \\
\hline
\end{tabular}

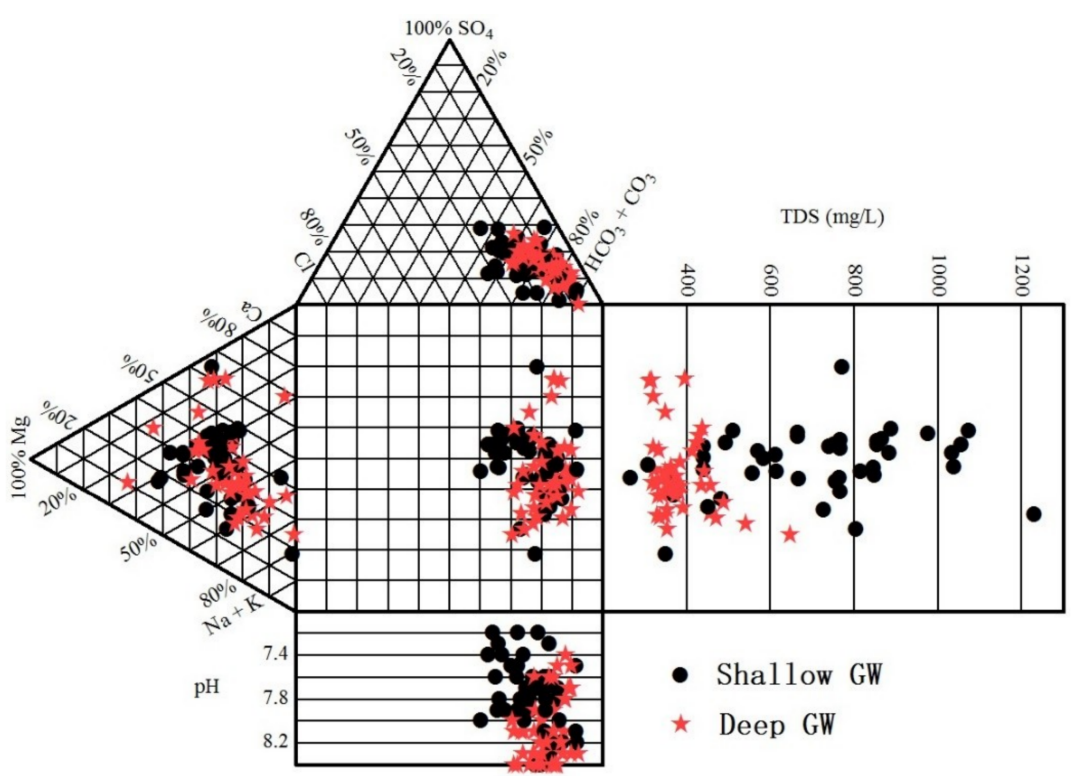

Figure 3. Durov diagram of groundwater samples. 


\subsection{Factors Controlling Groundwater Chemistry}

Understanding the main factors controlling groundwater chemistry is very important for groundwater sustainable development. For studying the formation mechanism of groundwater, Gibbs diagrams [29], which divides the groundwater formation mechanism into rock, evaporation, and precipitation dominance, are used in the present study. As shown in Figure 4, all of the samples are plotted in the middle area of Gibbs diagrams, indicating that rock weathering is the main natural factor controlling groundwater chemistry in the study area. However, the trend of shallow groundwater samples, being plotted from rock dominance to evaporation dominance, indicating that evaporation is also responsible for shallow groundwater chemistry evolution in some degree [23]. It should be noted that Gibbs diagrams can analyze the main natural factors controlling groundwater evolution, but they are unable to identify the influence of human activities on groundwater chemistry.
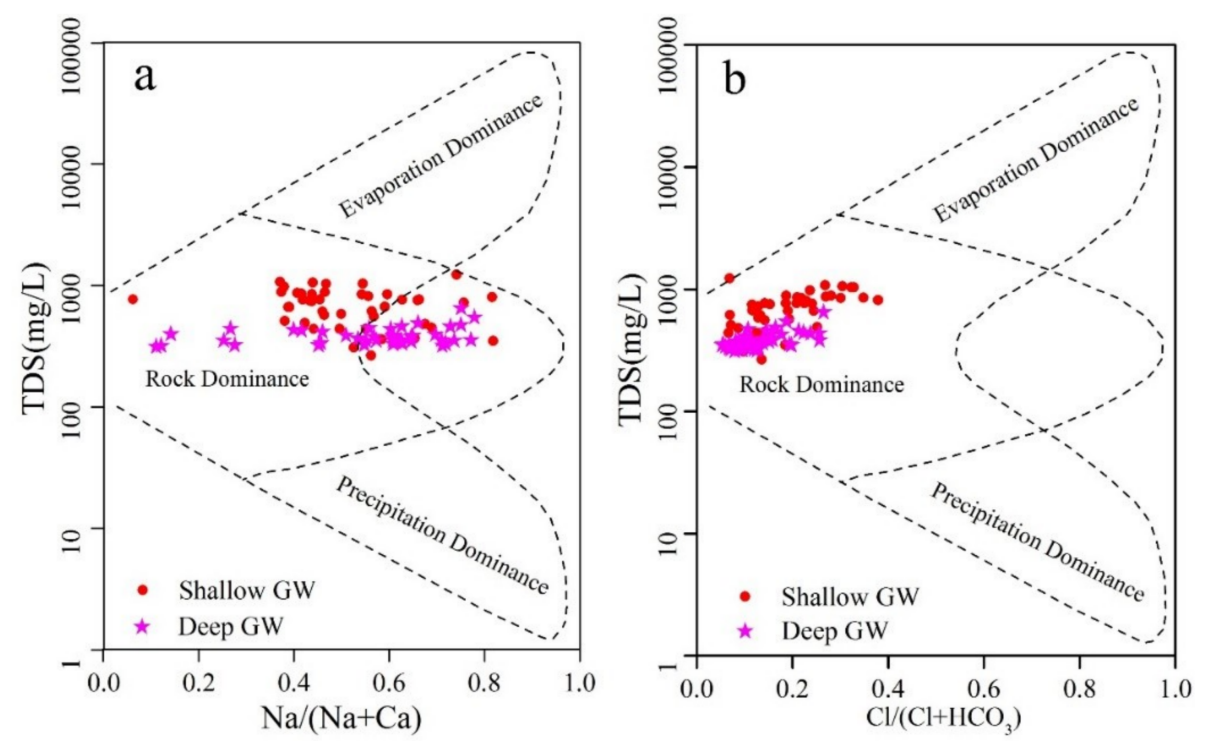

Figure 4. Gibbs diagrams showing the mechanism of groundwater evolution. (a) TDS vs. $\mathrm{Na}^{+} /\left(\mathrm{Na}^{+}+\mathrm{Ca}^{2+}\right)$; (b) TDS vs. $\mathrm{Cl}^{-} /\left(\mathrm{Cl}^{-}+\mathrm{HCO}_{3}{ }^{-}\right)$.

\subsubsection{Rock Weathering}

To further refine the weathering processes of rocks, some bivariate plots of major ions were performed (Figure 5). Figure 5a shows that most groundwater samples are situated along the halite dissolution line, suggesting that halite dissolution may be a contributing factor to $\mathrm{Na}^{+}$and $\mathrm{Cl}^{-}(1)$, as SI values of all the samples were less than 0 (Figure 6). However, most samples were observed deviating from the 1:1 line, indicates that the abundance of $\mathrm{Na}^{+}$is also influenced by some other processes, such as ion exchange and silicate hydrolysis (2) [6,30].

$$
\begin{gathered}
\mathrm{NaCl} \rightarrow \mathrm{Na}^{+}+\mathrm{Cl}^{-} \\
2 \mathrm{NaAlSi}_{3} \mathrm{O}_{8}+2 \mathrm{CO}_{2}+11 \mathrm{H}_{2} \mathrm{O} \rightarrow 2 \mathrm{Na}^{+}+\mathrm{Al}_{2} \mathrm{Si}_{2} \mathrm{O}_{5}(\mathrm{OH})_{4}+3 \mathrm{H}_{4} \mathrm{SiO}_{4}+2 \mathrm{HCO}_{3}^{-}
\end{gathered}
$$



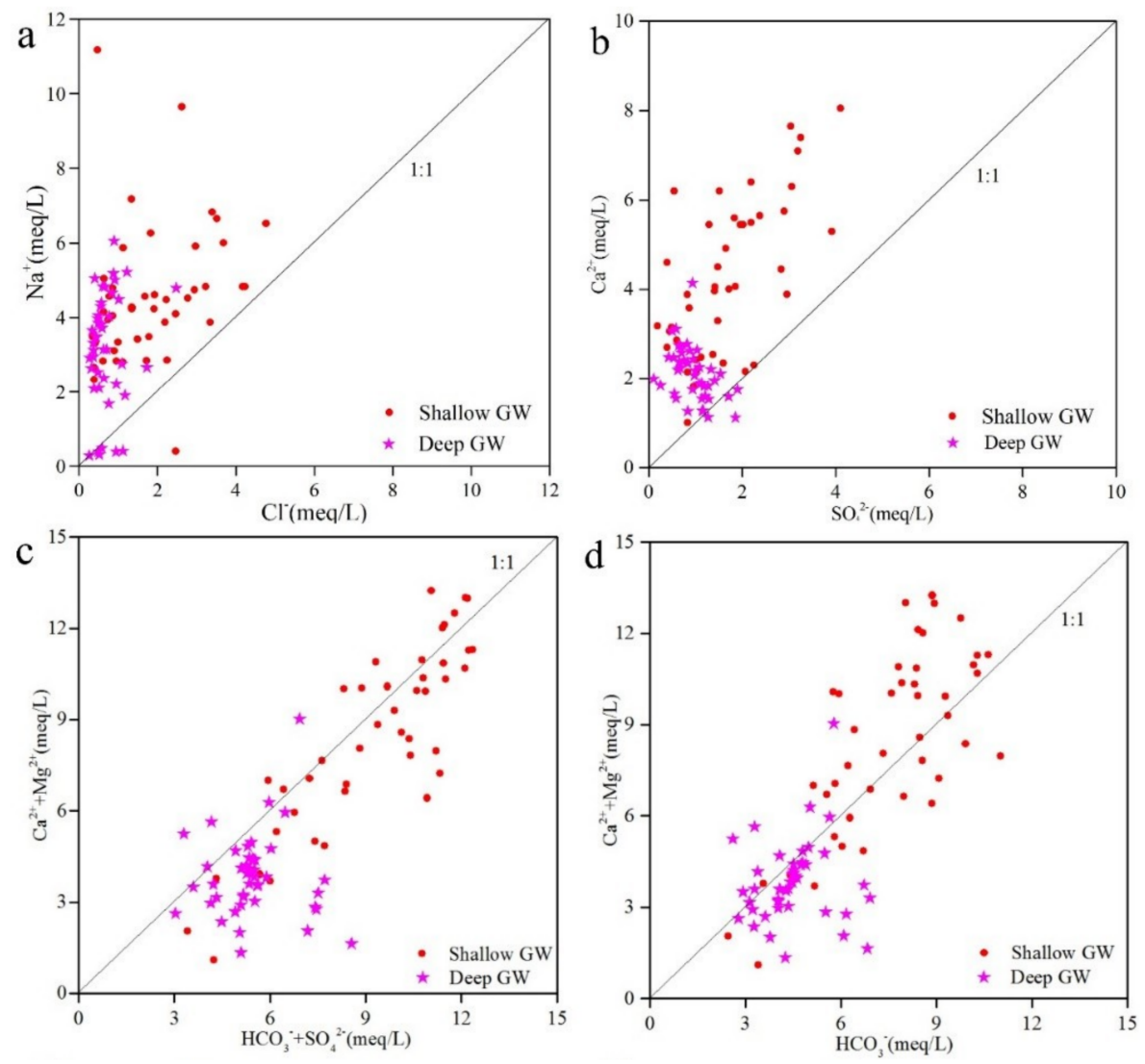

Figure 5. Bivariate plot of different ions showing the correlation of major ions to discriminate the chemical processes. (a) $\mathrm{Na}^{+}$vs. $\mathrm{Cl}^{-}$, (b) $\mathrm{Ca}^{2+}$ vs. $\mathrm{SO}_{4}{ }^{2-}$, (c) $\left(\mathrm{Ca}^{2+}+\mathrm{Mg}^{2+}\right)$ vs. $\left(\mathrm{HCO}_{3}{ }^{-}+\mathrm{SO}_{4}{ }^{2-}\right)$, (d) $\left(\mathrm{Ca}^{2+}+\mathrm{Mg}^{2+}\right)$ vs. $\mathrm{HCO}_{3}^{-}$.

As shown in Figure $5 b, \mathrm{Ca}^{2+}$ increases with $\mathrm{SO}_{4}{ }^{2-}$ and the ratios of $\mathrm{Ca}^{2+} / \mathrm{SO}_{4}{ }^{2-}$ are close to 1 in both shallow and deep groundwater, demonstrating that anhydrite and gypsum may be the sources of the two ions ( 3 and 4). All samples are under-saturated with the respect of anhydrite and gypsum (Figure 6), indicating that anhydrite and gypsum can continually dissolve in groundwater. While most samples fall above the 1:1 line (Figure 5b), suggesting that $\mathrm{Ca}^{2+}$ may also result from other chemical processes.

$$
\begin{gathered}
\mathrm{CaSO}_{4} \cdot 2 \mathrm{H}_{2} \mathrm{O} \rightarrow \mathrm{Ca}^{2+}+\mathrm{SO}_{4}^{2-}+2 \mathrm{H}_{2} \mathrm{O} \\
\mathrm{CaSO}_{4} \rightarrow \mathrm{Ca}^{2+}+\mathrm{SO}_{4}^{2-}+2 \mathrm{H}_{2} \mathrm{O}
\end{gathered}
$$

The plot of $\mathrm{Ca}^{2+}+\mathrm{Mg}^{2+}$ versus $\mathrm{HCO}_{3}{ }^{-}+\mathrm{SO}_{4}{ }^{2+}$ can reveal the contribution of the dissolution of sulfates (such as anhydrite and gypsum) and carbonate minerals (such as calcite and dolomite) to groundwater chemistry (5) and (6). Figure $5 \mathrm{c}$ shows that majority of the samples falls along the 1:1 line, signifying that the dissolution of sulfates and carbonate minerals is the main source of $\mathrm{Ca}^{2+}$, $\mathrm{Mg}^{2+}, \mathrm{HCO}_{3}{ }^{-}$, and $\mathrm{SO}_{4}{ }^{2+}$ [31]. Figure $5 \mathrm{~d}$ shows that most samples fall along the 1:1 line of $\mathrm{Ca}^{2+}+$ $\mathrm{Mg}^{2+}$ versus $\mathrm{HCO}_{3}{ }^{-}$diagram, suggesting that the dissolution of carbonates is one of the potential contributions of $\mathrm{Ca}^{2+}$. This is the reason that values of $\mathrm{Ca}^{2+} / \mathrm{SO}_{4}{ }^{2+}$ of most samples are higher than 1 (Figure $5 b$ ). However, most samples are oversaturated with respect to calcite, aragonite, and dolomite, indicating that the dissolution of these three minerals is not the dominated contribution to $\mathrm{Ca}^{2+}$ in groundwater.

$$
\begin{gathered}
\mathrm{CaCO}_{3}+\mathrm{CO}_{2}+\mathrm{H}_{2} \mathrm{O} \rightarrow \mathrm{Ca}^{2+}+2 \mathrm{HCO}_{3}^{-} \\
\mathrm{CaMg}\left(\mathrm{CO}_{3}\right)_{2}+2 \mathrm{CO}_{2}+2 \mathrm{H}_{2} \mathrm{O} \rightarrow \mathrm{Mg}^{2+}+\mathrm{Ca}^{2+}+4 \mathrm{HCO}_{3}^{-}
\end{gathered}
$$




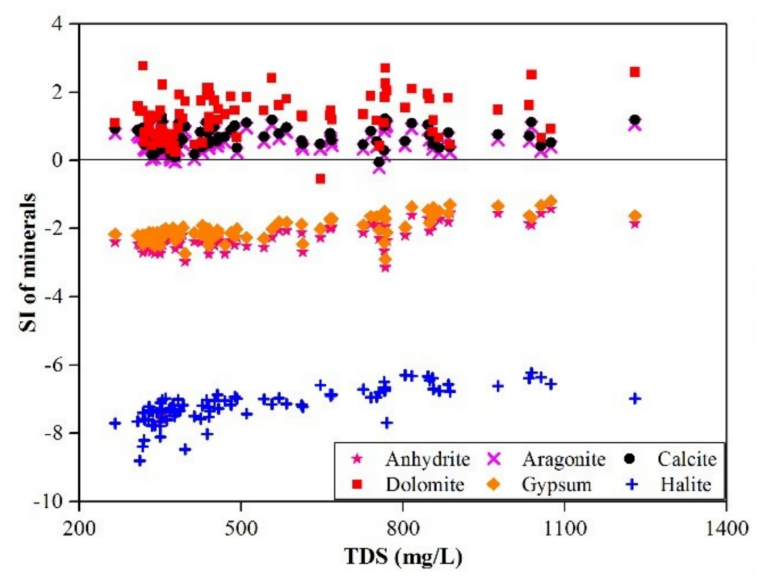

Figure 6. Relationships of saturation indices of selected minerals with total dissolved solids (TDS).

\subsubsection{Ion Exchange}

Cation exchange between $\mathrm{Na}^{+}$and $\mathrm{Ca}^{2+}$ is an important natural process with significant influences on groundwater chemistry. Two chloro-alkaline indices (CAI-1 and CAI-2), as proposed by Schoeller [32], were introduced in the present study to examine the effects of cation exchange on groundwater chemistry. They are defined as following (all ions are expressed by meq/L):

$$
\begin{gathered}
\mathrm{CAI}-1=\frac{\mathrm{Cl}^{-}-\left(\mathrm{Na}^{+}+\mathrm{K}^{+}\right)}{\mathrm{Cl}^{-}} \\
\mathrm{CAI}-2=\frac{\mathrm{Cl}^{-}-\left(\mathrm{Na}^{+}+\mathrm{K}^{+}\right)}{\mathrm{HCO}_{3}^{-}+\mathrm{SO}_{4}^{2-}+\mathrm{CO}_{3}^{-}+\mathrm{NO}_{3}^{-}}
\end{gathered}
$$

As shown in Figure $7 \mathrm{a}$, about $94.25 \%$ of the samples had negative values of these two chloro-alkaline indices, indicating that exchange of $\mathrm{Ca}^{2+}$ with $\mathrm{Na}^{+}$on aquifer materials (9) is the dominate cation exchange process in the study area. The bivariate diagram of $\left(\mathrm{Ca}^{2+}+\mathrm{Mg}^{2+}\right)-\left(\mathrm{HCO}_{3}{ }^{-}\right.$ $+\mathrm{SO}_{4}{ }^{2-}$ ) versus $\left(\mathrm{Na}^{+}+\mathrm{K}^{+}-\mathrm{Cl}^{-}\right)$shows that most samples plot at lower right part of the diagram. It conforms a linear formula with the fitted slop of -0.923 , confirming the existence of the exchange process expressed as R7. While the fitted slop is slightly lower than the theoretical value of -1 , indicating that other processes also influence the concentrations of $\mathrm{Na}^{+}, \mathrm{K}^{+}, \mathrm{Ca}^{2+}$, and $\mathrm{Mg}^{2+}$ in groundwater [23].

$$
\mathrm{Ca}^{2+}+2 \mathrm{NaX} \rightarrow 2 \mathrm{Na}^{+}+\mathrm{CaX}_{2}
$$
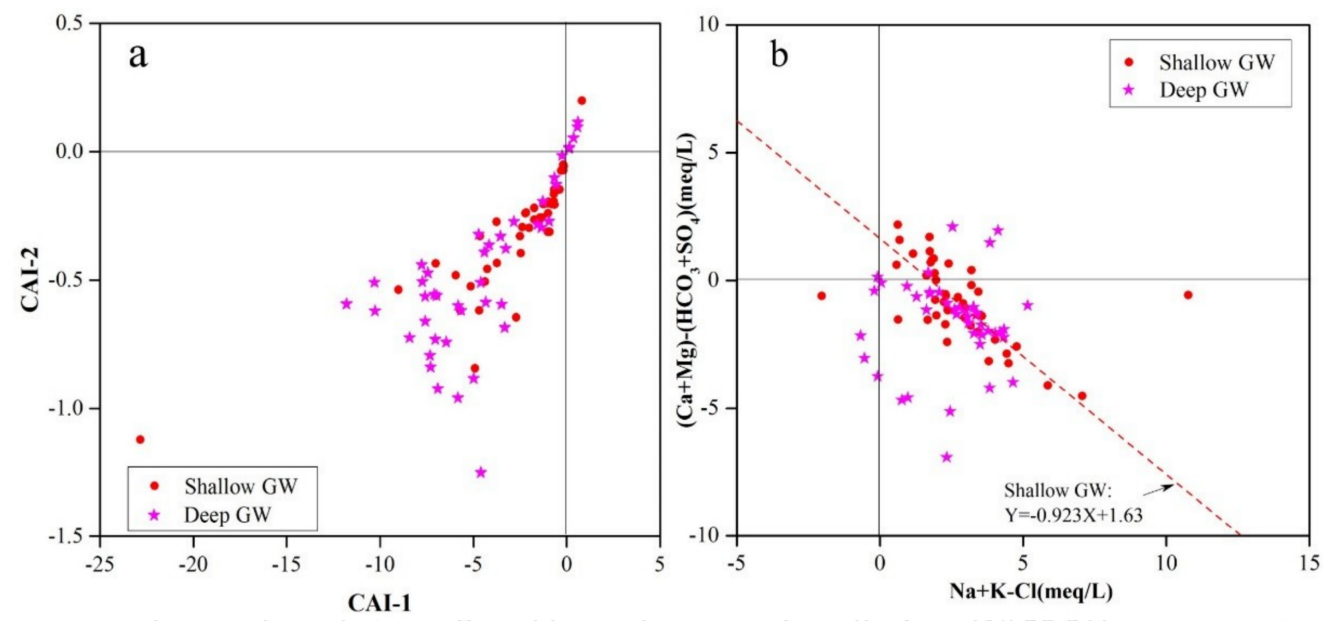

Figure 7. Plots of (a) CAI-1 against CAI-2 and (b) $\left(\mathrm{Ca}^{2+}+\mathrm{Mg}^{2+}\right)-\left(\mathrm{SO}_{4}{ }^{2-}+\mathrm{HCO}_{3}{ }^{-}\right)$versus $\mathrm{Na}^{+}+\mathrm{K}^{+}-\mathrm{Cl}^{-}$. 


\subsubsection{Evaporation}

Evaporation is one of the important natural processes influencing groundwater chemistry in the study area. Deuterium and oxygen-18 isotopes are useful tools to get insight into the effect of evaporation on groundwater chemical composition. The relationship of $\delta \mathrm{D}$ and $\delta^{18} \mathrm{O}$ for shallow groundwater is plotted in Figure 8. As shown in Figure 8, all of the samples of shallow groundwater fall below the local meteoric water line (LMWL), as established by Song et al. [33], indicating the strong evaporation effect on shallow groundwater chemistry in this area. A groundwater evaporation line (GEL), being expressed as (10), was obtained from shallow groundwater samples.

$$
\delta \mathrm{D}=5.25 \delta^{18} \mathrm{O}-18.71
$$

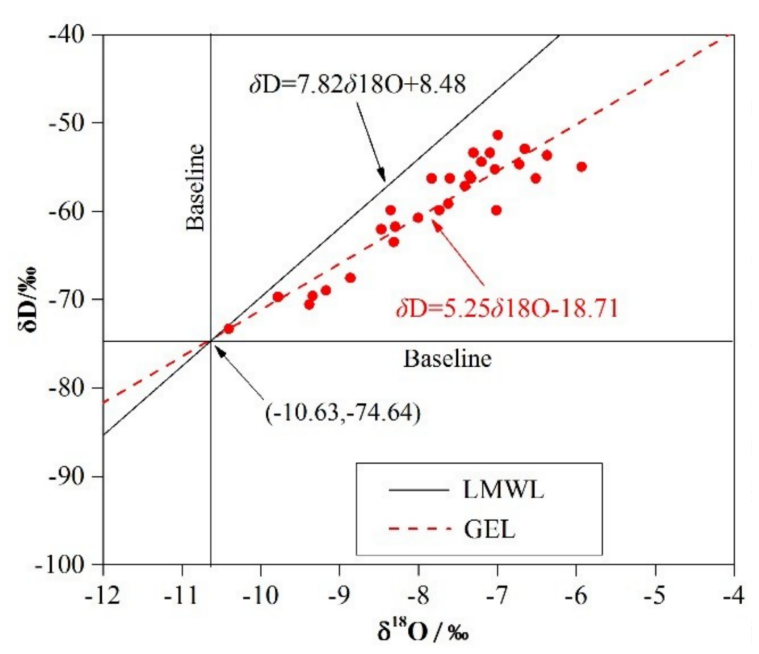

Figure 8. Plots of $\delta^{18} \mathrm{O}$ and $\delta \mathrm{D}$ of groundwater in the study area.

As shown in (10), the slop of GEL is smaller than that of LMWL, suggesting evaporation tends to enrich the heavy hydrogen and oxygen isotopes in shallow groundwater. Generally, the composition of hydrogen and oxygen stable isotopes in groundwater is rarely effected by water-rock interactions below $60^{\circ} \mathrm{C}$, and could remain relatively stable if there is no evaporation [23]. This means that the enrichment of heavy isotope can reflect the evaporation of groundwater in the area. Figure 8 shows that GEL intersects LMWL at $(-10.63,-74.64)$, and the values of this intersection are regarded as the baseline values of $\delta \mathrm{D}$ and $\delta^{18} \mathrm{O}$ for recharging rainfall in this area. As shown in Figure 8, all the samples are plotted at the right of baseline for $\delta \mathrm{D}$ and above the baseline for $\delta^{18} \mathrm{O}$, confirming that shallow groundwater chemistry is also influenced by evaporation.

\subsubsection{Human Activities}

Human activities, such as wastewater effluents, irrigation, fertilizer application, and groundwater abstraction, have been found to have a great influence on groundwater quality $[9,34,35]$. Due to the complexion and uncertainties of human activities, it is difficult to interpret the correlation between groundwater chemistry and human activities $[1,23] . \mathrm{NO}_{3}{ }^{-}$is one of the common contaminations related to human activities in groundwater, being widely used to study the influences of human activities on groundwater chemistry [24,27]. As shown in Figure 9, TDS in shallow groundwater has positive correlation with $\left(\mathrm{NO}_{3}{ }^{-}+\mathrm{Cl}^{-}\right) / \mathrm{HCO}_{3}{ }^{-}$and the pearson correlation coefficient is $0.303(p<0.05)$, indicating that shallow groundwater chemistry composition has been influenced by anthropogenic inputs [35]. While the correlation between TDS and $\left(\mathrm{NO}_{3}{ }^{-}+\mathrm{Cl}^{-}\right) / \mathrm{HCO}_{3}{ }^{-}$in deep groundwater is not obvious, demonstrating that human activities have rare influences on deep groundwater quality. When considering the long history of wastewater and reclaimed water irrigation, 
as well as fertilizer application, it is a common phenomenon that groundwater, especially shallow groundwater, have been polluted by anthropogenic pollutions $[18,23,36]$.

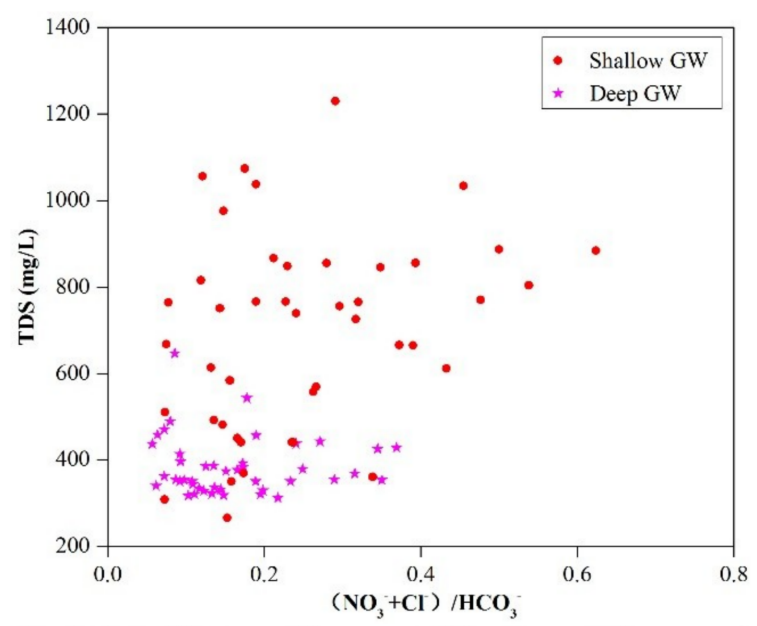

Figure 9. Bivariate diagram of TDS versus $\left(\mathrm{NO}_{3}{ }^{-}+\mathrm{Cl}^{-}\right) / \mathrm{HCO}_{3}{ }^{-}$.

\subsection{Groundwater Suitability}

\subsubsection{Drinking Purpose}

Water quality index (WQI) is an simple and useful approach for determining the overall quality of groundwater and its suitability for drinking purposes, and it has been widely used over the world [37]. However, the traditional WQI approach uses empirical values as the weight of each chemical parameter without many valuable information of groundwater quality. Therefore, the results cannot reflect the truth of groundwater quality. In this study, an improved WQI approach with entropy weight (entropy weight water quality index, EWQI) was introduced to assess overall quality of groundwater. The procedures and details of EWQI have been described by Amiri et al. [38] as the Supplementary material. The drinking water standards (WHO 2011) [28] and overall groundwater quality classification criteria of EWQI are listed in Tables 1 and 2, respectively. The EWQI results of this study are shown in Figure 10.

As shown in Figure 10, most deep groundwater samples are placed in the "excellent" quality (rank 1), and the majority of the shallow groundwater samples are located in "good" and "medium" quality (rank 2 and 3). Among 43 deep groundwater samples, 31 are "excellent" quality (rank 1) water samples, and 12 are of "good" quality (rank 2), accounting for $72.09 \%$ and $27.91 \%$, respectively. Among 44 shallow groundwater samples, 1 is of "excellent" quality (rank 1), 25 are of "good" quality (rank 2), and 18 are of "medium" quality (rank 3), accounting for $2.27 \%, 56.82 \%$, and $40.91 \%$, respectively. The calculation results of EWQI indicate that deep groundwater in the study area is excellent for drinking purposes, while shallow groundwater, with the water quality mainly ranging from good to medium, is not as excellent as the deep groundwater for drinking purpose. The difference of water quality between shallow and deep groundwater also confirms that human activities and evaporation are the responsible factors, resulting in the relative poor quality of shallow groundwater. 


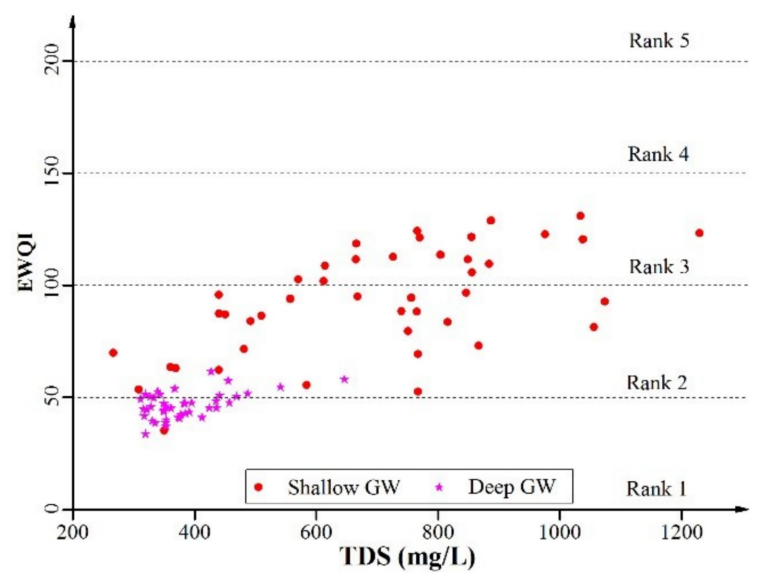

Figure 10. Bivariate diagram of entropy weighted water quality index (EWQI) versus TDS.

Table 2. Classification criteria of groundwater quality base on EWQI.

\begin{tabular}{ccc}
\hline EWQI & Rank & Water Quality \\
\hline$<50$ & 1 & Excellent \\
$50-100$ & 2 & Good \\
$100-150$ & 3 & Medium \\
$150-200$ & 4 & Poor \\
$>200$ & 5 & Extremely poor \\
\hline
\end{tabular}

\subsubsection{Irrigation Purpose}

Groundwater suitability for irrigation mainly depends on the concentration of total salinity and sodium related to other ions [39]. Therefore, salinity hazard and sodium hazard are the core issues concerned in irrigation water quality assessment. In this study, the suitability of groundwater for irrigation is evaluated by electrical conductivity (EC), adsorption ratio (SAR), solute sodium percentage $(\% \mathrm{Na})$, and Permeability index (PI). Table 3 lists the criteria of irrigation water quality classifications that are based on EC, SAR, and \%Na [40].

EC, a measure of the total salinity, is usually used to classify irrigation water quality. According to the criteria based on EC (Table 3), $86.36 \%$ and $13.64 \%$ of deep groundwater samples had EC values ranging from $250 \mu \mathrm{S} / \mathrm{cm}$ to $750 \mu \mathrm{S} / \mathrm{cm}$ and between $750 \mu \mathrm{S} / \mathrm{cm}$ and $2250 \mu \mathrm{S} / \mathrm{cm}$, respectively (Figure 11), indicating good and acceptable quality for irrigation; and, $23.26 \%$ and $76.74 \%$ of shallow groundwater samples are with EC values in the range of $250-750 \mu \mathrm{S} / \mathrm{cm}$ and $750-2250 \mu \mathrm{S} / \mathrm{cm}$ (Figure 11), respectively, demonstrating good and acceptable quality for irrigation. The quality of deep groundwater is better than shallow groundwater for irrigation with respect to EC values.

Table 3. Criteria of irrigation water quality classifications based on EC, SAR, \%Na and RSC.

\begin{tabular}{ccccc}
\hline EC & SAR & Irrigation Water Quality & $\mathbf{\% N a}$ & Irrigation Water Quality \\
\hline$<250$ & $<10$ & Excellent & $<30$ & Suitable \\
$250-750$ & $10-18$ & Good & $30-60$ & Marginally suitable \\
$750-2250$ & $18-26$ & Acceptable & $>60$ & Unsuitable \\
$>2250$ & $>26$ & Unacceptable & & \\
\hline
\end{tabular}

SAR is a measure of soil capacity to adsorb sodium from agricultural irrigation water and thus a significant parameter to determine possibility of sodium/alkali hazard to crops. SAR is obtained using (11). The concentrations of all ions in (11) are expressed in meq/L. According to the criteria that 
are based on SAR in Table 3, all the samples of shallow and deep groundwater in the study area had excellent quality for irrigation.

$$
\mathrm{SAR}=\frac{\mathrm{Na}^{+}}{\sqrt{\frac{\mathrm{Ca}^{2+}+\mathrm{Mg}^{2+}}{2}}}
$$

United States Salinity Laboratory (USSL) diagram [41] was applied to evaluate the suitability of water for agricultural irrigation purpose in this study. As shown in Figure 11, 23.26\%, 72.09\%, and $4.65 \%$ of shallow groundwater samples are plotted in C2S1 (medium salinity with low sodium hazard), C3S1 (high salinity with low sodium hazard), and C3S2 (high salinity with medium sodium hazard), respectively; and, $86.36 \%$ and $13.64 \%$ of deep groundwater fall in the C2S1 and C3S1, respectively. All of the above indicates that both shallow and deep groundwater are with good to acceptable quality for agricultural purpose, but deep groundwater is more suitable for irrigation than shallow groundwater.

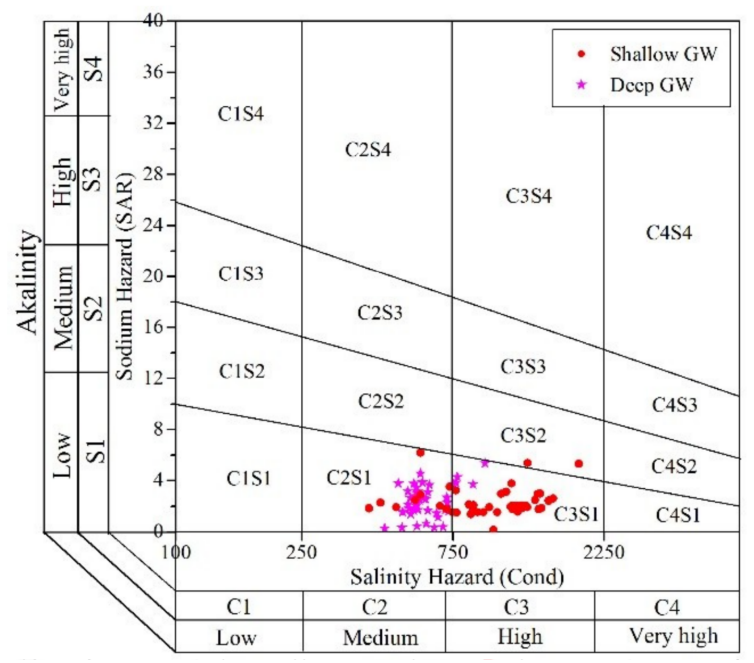

Figure 11. USSL diagram for groundwater in shallow and deep aquifers.

$\% \mathrm{Na}$ is another important parameter to indicate the suitability of water for irrigation. It is calculated by (12). All the cations in Equation (12) are expressed in meq/L. According to the Wilcox diagram (Figure 12), 20.93\%, 72.09\%, and 6.98\% of shallow groundwater samples belong to excellent to good, good to permissible, permissible to suitable categories for irrigation, respectively; and, most of the deep groundwater samples (88.64\%) belong to the excellent to good category, while $4.55 \%$ and $6.82 \%$ belong to good to permissible and permissible to suitable categories, respectively.

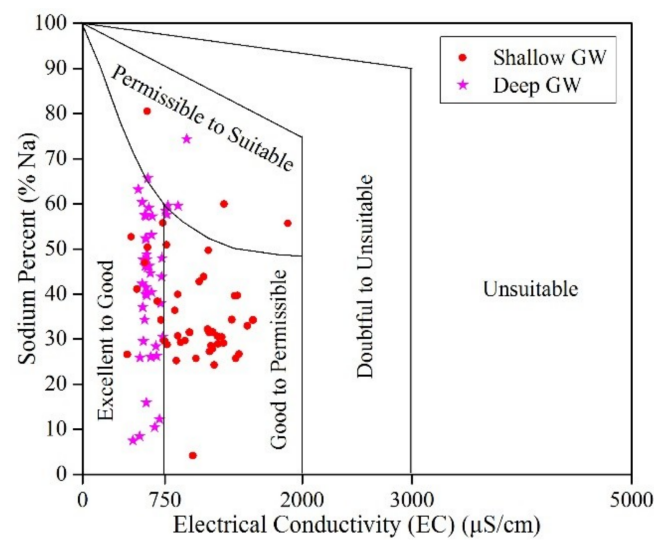

Figure 12. Wilcox diagram (\%Na vs. EC) for assessing Irrigation water quality. 


$$
\% \mathrm{Na}=\frac{\mathrm{Na}^{+}}{\mathrm{Ca}^{2+}+\mathrm{Mg}^{2+}+\mathrm{Na}^{+}+\mathrm{K}^{+}}
$$

Permeability is an important physical property of soil that may be influenced by long-term use of irrigation water [5]. Permeability index (PI), which represented by (13), is widely used to determine the influence of long-term irrigation on soil hydraulic property [42]. According to PI values, irrigation water is divided into three classes: Class-I is of excellent quality, Class-II is acceptable for irrigation, and Class-III is unsuitable water for irrigation. As shown in Figure 13, 86.05\% of shallow groundwater samples are classified into Class-I, $11.63 \%$ into Class-II, and $2.33 \%$ into Class-III; $18.18 \%, 75.00 \%$, and $6.82 \%$ of deep groundwater samples belong to Class-I, II, and III, respectively. The classified results indicate that most of the shallow and deep groundwater samples are suitable for long-term irrigation without influence on soil property, except one shallow and three deep groundwater samples.

$$
\mathrm{PI}=\frac{\mathrm{Na}^{+}+\sqrt{\mathrm{HCO}_{3}^{-}}}{\mathrm{Ca}^{2+}+\mathrm{Mg}^{2+}+\mathrm{Na}^{+}} \times 100 \%
$$

Overall, both shallow and deep groundwater are suitable for irrigation purpose and they may not induce salinity and sodium hazard. However, there are one shallow and three deep groundwater samples with high PI values, the long-term use of which may affect the soil property and influence the yields of crop. Therefore, the long-term use of these four groundwater samples for irrigation should be avoided.

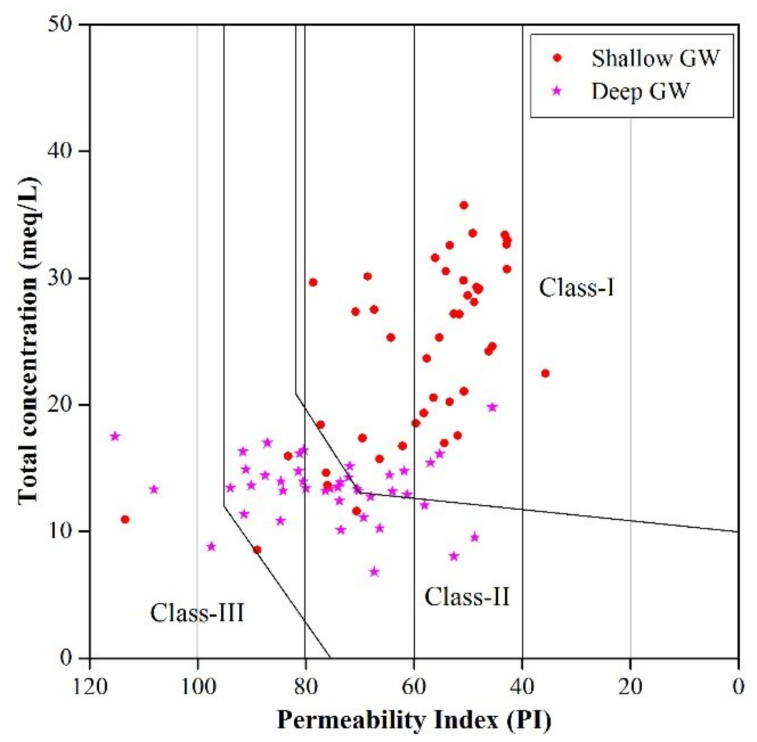

Figure 13. Classification of irrigation water based on permeability index.

\section{Conclusions}

The shortage of water sources led to long-term use of wastewater and reclaimed water for irrigation in the semi-arid regions, and it may threaten the quality of groundwater as well. In the present study, factors influencing groundwater chemistry and its quality in Beijing were discussed in detail. Groundwater quality assessments were also introduced to evaluate the suitability for drinking and irrigation purpose. The achieved conclusions were following:

Groundwater in both shallow and deep aquifers in the study area is weakly alkaline freshwater. The abundance is in the order $\mathrm{Na}^{+}>\mathrm{Ca}^{2+}>\mathrm{Mg}^{2+}>\mathrm{K}^{+}$for cations, and $\mathrm{HCO}_{3}{ }^{-}>\mathrm{SO}^{2-}>\mathrm{Cl}^{-}$for anions, resulting that the water types of both shallow and deep groundwater were dominated by $\mathrm{HCO}_{3}-\mathrm{Na} \cdot \mathrm{Mg} \cdot \mathrm{Ca}, \mathrm{HCO}_{3}-\mathrm{Mg} \cdot \mathrm{Ca} \cdot \mathrm{Na}, \mathrm{HCO}_{3}-\mathrm{Ca} \cdot \mathrm{Na}$ and $\mathrm{HCO}_{3}-\mathrm{Na}$. 
Water-rock interactions, including rock weathering and ion exchange are the dominant factors controlling groundwater chemistry in both shallow and deep aquifers. The dissolutions of halite, gypsum, anhydrite, silicates and ion exchange are the main reactions forming composition for both shallow and deep groundwater. While shallow groundwater chemistry is also influenced by evaporation and anthropogenic inputs.

Quality assessment reveals that groundwater in both shallow and deep aquifers, in general, is suitable for drinking and irrigation purpose. According to the results of EWQI, the quality of shallow groundwater for drinking is mainly good to medium, and that of deep groundwater is better, showing dominantly excellent. The assessments based on SAR, \%Na, USSL classification, and Wilcox diagram show that both shallow and deep groundwater are of excellent to good categories for irrigation use without severe hazards, but the PI values indicate that one shallow groundwater and three deep groundwater have risks of soil quality deterioration. Groundwater in these locations should be avoided for agricultural irrigation. Overall, it is recommended that deep groundwater is preferentially used for drinking and domestic purpose, and shallow groundwater for agricultural irrigation.

Supplementary Materials: The following are available online at http:/ /www.mdpi.com/2073-4441/10/9/1209/ s1.

Author Contributions: Conceptualization, Y.X. and S.Y.; Methodology, Y.X. and X.G.; Formal Analysis, X.G and Q.H.; Investigation, Y.X. and H.Y.; Data Curation, H.L., Z.H. and G.M.; Writing-Original Draft Preparation, X.G.; Writing-Review \& Editing, Y.X. and Q.P.; Supervision, S.Y.

Funding: This research was funded by the National Basic Resources Survey Program of China (grant number: 2017FY100405) and a China Geological Survey Project (grant number: DD20160238).

Conflicts of Interest: The authors declare no conflict of interest. The funders had no role in the design of the study; in the collection, analyses, or interpretation of data; in the writing of the manuscript, and in the decision to publish the results.

\section{References}

1. Yu, Y.; Song, X.; Zhang, Y.; Zheng, F.; Ji, L.; Liu, L. Identifying spatio-temporal variation and controlling factors of chemistry in groundwater and river water recharged by reclaimed water at huai river, north china. Stoch. Environ. Res. Risk Assess. 2014, 28, 1135-1145. [CrossRef]

2. Liang, C.P.; Jang, C.S.; Chen, C.F.; Chen, J.S. Zonal management of multi-purposes groundwater utilization based on water quality and impact on the aquifer. Environ. Monit. Assess. 2016, 188, 431. [CrossRef] [PubMed]

3. Zhai, Y.; Wang, J.; Teng, Y.; Zuo, R. Hydrogeochemical and isotopic evidence of groundwater evolution and recharge in aquifers in beijing plain, china. Environ. Earth Sci. 2013, 69, 2167-2177. [CrossRef]

4. Jang, C.S.; Chen, C.F.; Liang, C.P.; Chen, J.S. Combining groundwater quality analysis and a numerical flow simulation for spatially establishing utilization strategies for groundwater and surface water in the pingtung plain. J. Hydrol. 2016, 533, 541-556. [CrossRef]

5. Davraz, A.; Özdemir, A. Groundwater quality assessment and its suitability in Çeltikçi plain (burdur/turkey). Environ. Earth Sci. 2014, 72, 1167-1190. [CrossRef]

6. Xiao, Y.; Shao, J.; Frape, S.K.; Cui, Y.; Dang, X.; Wang, S.; Ji, Y. Groundwater origin, flow regime and geochemical evolution in arid endorheic watersheds: A case study from the qaidam basin, northwestern china. Hydrol. Earth Syst. Sci. 2018, 22, 4381-4400. [CrossRef]

7. Liang, C.-P.; Wang, S.-W.; Kao, Y.-H.; Chen, J.-S. Health risk assessment of groundwater arsenic pollution in southern taiwan. Environ. Geochem. Health 2016, 38, 1271-1281. [CrossRef] [PubMed]

8. Zhou, Y.; Xiao, W.; Wang, J.; Zhao, Y.; Huang, Y.; Tian, J.; Chen, Y. Evaluating spatiotemporal variation of groundwater depth/level in beijing plain, a groundwater-fed area from 2001 to 2010. Adv. Meteorol. 2016, 2016, 2714209. [CrossRef]

9. Xiao, Y.; Gu, X.; Yin, S.; Pan, X.; Shao, J.; Cui, Y. Investigation of geochemical characteristics and controlling processes of groundwater in a typical long-term reclaimed water use area. Water 2017, 9, 800. [CrossRef]

10. Chen, W.; Lu, S.; Jiao, W.; Wang, M.; Chang, A.C. Reclaimed water: A safe irrigation water source? Environ. Dev. 2013, 8, 74-83. [CrossRef] 
11. Chen, W.; Lu, S.; Pan, N.; Jiao, W. Impacts of long-term reclaimed water irrigation on soil salinity accumulation in urban green land in beijing. Water Resour. Res. 2013, 49, 7401-7410. [CrossRef]

12. Chen, W.; Lu, S.; Pan, N.; Wang, Y.; Wu, L. Impact of reclaimed water irrigation on soil health in urban green areas. Chemosphere 2015, 119, 654-661. [CrossRef] [PubMed]

13. Wang, F.H.; Qiao, M.; Lv, Z.E.; Guo, G.X.; Jia, Y.; Su, Y.H.; Zhu, Y.G. Impact of reclaimed water irrigation on antibiotic resistance in public parks, beijing, china. Environ. Pollut. 2013, 184C, 247-253. [CrossRef] [PubMed]

14. Wu, W.; Yin, S.; Liu, H.; Niu, Y.; Bao, Z. The geostatistic-based spatial distribution variations of soil salts under long-term wastewater irrigation. Environ. Monit. Assess. 2014, 186, 6747-6756. [CrossRef] [PubMed]

15. Zhao, Y.; Han, S.S.; Chen, Z.F.; Liu, J.; Hu, H.X. Comparative study of heavy metals in "soil-wheat" systems between sewage-irrigated areas and clean-water-irrigated areas in suburban beijing. J. Environ. Health 2015, 77, 28-34. [PubMed]

16. Bao, Z.; Wu, W.; Liu, H.; Chen, H.; Yin, S. Impact of long-term irrigation with sewage on heavy metals in soils, crops, and groundwater-A case study in beijing. Pol. J. Environ. Stud. 2014, 23, 309-318.

17. Niu, Y.; Yin, S.; Liu, H.; Wu, W.; Li, B. Use of geostatistics to determine the spatial variation of groundwater quality: A case study in beijing's reclaimed water irrigation area. Pol. J. Environ. Stud. 2015, 24, 611-618.

18. Wang, S.; Wu, W.; Liu, F.; Yin, S.; Bao, Z.; Liu, H. Spatial distribution and migration of nonylphenol in groundwater following long-term wastewater irrigation. J. Contam. Hydrol. 2015, s177-s178, 85-92. [CrossRef] [PubMed]

19. Bao, Z.; Wu, W.; Liu, H.; Yin, S.; Chen, H. Geostatistical analyses of spatial distribution and origin of soil nutrients in long-term wastewater-irrigated area in Beijing, China. Acta Agric. Scand. Sect. B Soil Plant Sci. 2014, 64, 235-243. [CrossRef]

20. Huang, G.; Chen, Z.; Liu, F.; Sun, J.; Wang, J. Impact of human activity and natural processes on groundwater arsenic in an urbanized area (South China) using multivariate statistical techniques. Environ. Sci. Pollut. Res. 2014, 21, 13043-13054. [CrossRef] [PubMed]

21. Liu, J.; Chen, Z.; Zhang, Y.; Li, Z.; Zhang, L.; Liu, F. Stable isotope evidences on sources and mechanisms of groundwater recharge in hohhot basin, China. Environ. Earth Sci. 2016, 75, 410. [CrossRef]

22. Wu, W. Research on Groundwater Vulnerability Experiment of Reclaimed Wastewater District and Irrigation Allocation; China University of Geosciences: Beijing, China, 2009.

23. Li, P.; Wu, J.; Qian, H.; Zhang, Y.; Yang, N.; Jing, L.; Yu, P. Hydrogeochemical characterization of groundwater in and around a wastewater irrigated forest in the southeastern edge of the tengger desert, Northwest China. Expo. Health 2016, 8, 331-348. [CrossRef]

24. Esmaeili, A.; Moore, F.; Keshavarzi, B. Nitrate contamination in irrigation groundwater, Isfahan, Iran. Environ. Earth Sci. 2014, 72, 2511-2522. [CrossRef]

25. Vikas, C.; Kushwaha, R.; Ahmad, W.; Prasannakumar, V.; Dhanya, P.V.; Reghunath, R. Hydrochemical appraisal and geochemical evolution of groundwater with special reference to nitrate contamination in aquifers of a semi-arid terrain of NW India. Water Qual. Expo. Health 2014, 7, 347-361. [CrossRef]

26. Zhang, Q.Q.; Sun, J.C.; Liu, J.T.; Huang, G.X.; Lu, C.; Zhang, Y.X. Driving mechanism and sources of groundwater nitrate contamination in the rapidly urbanized region of south china. J. Contam. Hydrol. 2015, 182, 221-230. [CrossRef] [PubMed]

27. Karagüzel, R.; Irlayici, A. Groundwater pollution in the isparta plain, Turkey. Environ. Geol. 1998, 34, 303-308. [CrossRef]

28. WHO. Guidelines for Drinking-Water Quality, 4th ed.; World Health Organization: Geneva, Switzerland, 2011.

29. Gibbs, R.J. Mechanisms controlling world water chemistry. Science 1970, 170, 1088-1090. [CrossRef] [PubMed]

30. Farid, I.; Zouari, K.; Rigane, A.; Beji, R. Origin of the groundwater salinity and geochemical processes in detrital and carbonate aquifers: Case of chougafiya basin (Central Tunisia). J. Hydrol. 2015, 530, 508-532. [CrossRef]

31. Chung, S.Y.; Venkatramanan, S.; Kim, T.H.; Kim, D.S.; Ramkumar, T. Influence of hydrogeochemical processes and assessment of suitability for groundwater uses in busan city, Korea. Environ. Dev. Sustain. 2015, 17, 423-441. [CrossRef]

32. Schoeller, H. Qualitative evaluation of groundwater resources. In Methods and Techniques of Groundwater Investigations and Development; UNESCO: Paris, France, 1965; pp. 54-83. 
33. Song, X.; Liu, X.; Xia, J.; Jingjie, Y.U.; Tang, C. A study of interaction between surface water and groundwater using environmental isotope in huaisha river basin. Sci. China 2006, 49, 1299-1310. [CrossRef]

34. Jalali, M. Geochemistry characterization of groundwater in an agricultural area of razan, hamadan, Iran. Environ. Geol. 2009, 56, 1479-1488. [CrossRef]

35. Marghade, D.; Malpe, D.B.; Zade, A.B. Major ion chemistry of shallow groundwater of a fast growing city of central india. Environ. Monit. Assess. 2012, 184, 2405-2418. [CrossRef] [PubMed]

36. Gu, X.; Xiao, Y.; Yin, S.; Pan, X.; Niu, Y.; Shao, J.; Cui, Y.; Zhang, Q.; Hao, Q. Natural and anthropogenic factors affecting the shallow groundwater quality in a typical irrigation area with reclaimed water, North China plain. Environ. Monit. Assess. 2017, 189, 514. [CrossRef] [PubMed]

37. Vasanthavigar, M.; Srinivasamoorthy, K.; Vijayaragavan, K.; Ganthi, R.R.; Chidambaram, S.; Anandhan, P.; Manivannan, R.; Vasudevan, S. Application of water quality index for groundwater quality assessment: Thirumanimuttar sub-basin, tamilnadu, india. Environ. Monit. Assess. 2010, 171, 595-609. [CrossRef] [PubMed]

38. Amiri, V.; Rezaei, M.; Sohrabi, N. Groundwater quality assessment using entropy weighted water quality index (EWQI) in Lenjanat, Iran. Environ. Earth Sci. 2014, 72, 3479-3490. [CrossRef]

39. Rao, N.S.; Subrahmanyam, A.; Kumar, S.R.; Srinivasulu, N.; Rao, G.B.; Rao, P.S.; Reddy, G.V. Geochemistry and quality of groundwater of gummanampadu sub-basin, guntur district, andhra pradesh, India. Environ. Earth Sci. 2012, 67, 1451-1471.

40. Patel, P.; Raju, N.J.; Reddy, B.C.S.R.; Suresh, U.; Gossel, W.; Wycisk, P. Geochemical processes and multivariate statistical analysis for the assessment of groundwater quality in the swarnamukhi river basin, andhra pradesh, India. Environ. Earth Sci. 2016, 75, 611. [CrossRef]

41. United States Salinity Laboratory. Diagnosis and Improvement of Salinity and Alkaline Soil; USDA Hand Book: Washington, DC, USA, 1954.

42. Nematollahi, M.J.; Ebrahimi, P.; Razmara, M.; Ghasemi, A. Hydrogeochemical investigations and groundwater quality assessment of torbat-zaveh plain, khorasan razavi, Iran. Environ. Monit. Assess. 2015, 188, 2. [CrossRef] [PubMed] 